\title{
Faktor-Faktor yang Mempengaruhi Pendapatan Keluarga Miskin di Kecamatan Panarukan Kabupaten Situbondo
}

\section{(Factors affect the income of poor families in Panarukan Situbondo City).}

\author{
Radhitia Brianjaya, I Wayan Subagiarta ${ }^{1}$, Zainuri \\ Jurusan Ilmu Ekonomi, Fakultas Ekonomi dan Bisnis, Universitas Jember (UNEJ) \\ Jln. Kalimantan 37, Jember 68121 \\ E-mail : wayansubagiarta.fe@unej.ac.id
}

\begin{abstract}
Abstrak
Tujuan penelitian ini adalah untuk mengetahui pengaruh pendidikan, jumlah partisipasi kerja keluarga, usia dan jenis pekerjaan terhadap pendapatan keluarga miskin di Kecamatan Panarukan Kabupaten Situbondo. Populasi penelitian ini adalah keluarga miskin di Kecamatan Panarukan Kabupaten Situbondo yang menerima bantuan rasikin yaitu sebanyak 3.118 kepala keluarga. Kemudian diambil sampel dengan teknik stratified random sampling dengan jumlah 97 orang. Metode yang digumnakan dalam penelitian ini adalah Ordinary Leas Square. Berdasarkan hasil penelitian yang diperoleh, dipeoleh hasil bahwa pendidikan, jumlah partisipasi kerja, usia dan jenis pekerjaan berpengaruh terhadap pendapatan keluarga miskin di Kecamatan Panarukan Kabupaten Situbondo. Maka dapat disimpulkan variabel independen secara bersama-sama berpengaruh terhadap variabel dependent, artinya variabel pendidikan, jumlah partisipasi kerja dan jenis pekerjaan mempunyai pengaruh yang positif dan signifikan, sedangkan usia mempunyai pengaruh yang negatif dan tidak signifikan.
\end{abstract}

Kata Kunci : Pendidikan, Partisipasi kerja, usia, dan jenis pekerjaan

\begin{abstract}
The purpose of this study was to determine the effect of education, number of the family work participation, age and type of work to the poor family income in Panarukan Situbondo district. This research population is 3.118 poor families in Panarukan Situbondo district. Then sampled by stratified random sampling with 97 people. The method used in this research is Ordinary Least Square. Based on the research result, the result thatresearch, the number of work participation, age and type of work affect the income of poor family in the district of Situbondo Panarukan. the result that education, the number of work participation, age and type of work affect the income of poor family in Panarukan Situbondo district. It can be concluded the independent variables simultaneously affect the dependent variable. variable means of education, the number of work participation and the type of work has a positive and significant effect, while age has a negative effect and insignificant.
\end{abstract}

Keywords : Education, work participation, age and type of work

\section{Pendahuluan}

Salah satu tujuan pembangunan nasioal Negara Indonesia sebagaimana diamanatkan dalam alinea keempat Pembukaan Undang-Undang Dasar 1945 yaitu untuk memajukan kesejahteraan umum. Kesejahteraan umum menurut Badan Pusat Statistik (2000) merupakan kondisi terpenuhinya kebutuhan material, spiritual, dan sosial penduduk negara agar dapat hidup layak dan mampu mengembangkan diri, sehingga dapat melaksanakan fungsi sosial dan ekonominya. Kesejahteraan umum di Indonesia dapat digambarkan salah satunya berdasarkan tingkat kemiskinan penduduk Indonesia, semakin rendah tingkat kemiskinan di Indonesia menggambarkan semakin tinggi kesejahteraan penduduk di Indonesia.

Pembangunan ekonomi di Indonesia saat ini sedang dihadapkan dengan kemiskinan. Pada umunya di negara berkembang seperti Indonesia permasalahan pendapatan yang rendah dengan masalah kemiskinan merupakan masalah utama dalam pembangunan ekonomi. Dengan demikian dalam tujuan ekonomi kedua masalah tersebut dinyatakan bersamaan sehingga menjadi satu kalimat yaitu peningkatan pendapatan nasional dan pengurangan kemiskinan.

Kemiskinan merupakan masalah kompleks yang dipengaruhi oleh berbagai faktor yang saling berkaitan, antara lain pengaruh jenis pekerjaan, pengaruh tingkat pendidikan, pengaruh usia terhadap penghasilan. Kemiskinan tidak lagi dipahami hanya sebatas ketidakmampuan ekonomi, tetapi juga kegagalan memenuhi hak-hak dasar yang diakui secara umum meliputi terpenuhinya kebutuhan pangan, kesehatan, pendidikan, pekerjaan dan sebagainya. Esensi kemiskinan adalah menyangkut kondisi kekurangan dari sebuah tuntutan kehidupan yang paling minimum.

Pembangunan adalah manifestasi dari suatu proses menuju kemajuan material perekonomian, sehingga ukuran-ukuran keberhasilan dapat terlihat dari besaran indikator ekonomi pertumbuhan GDP, pertumbuhan PDRB, proses akumulasi modal untuk investasi, dan tingkat konsumsi masyarakat. Dengan karakteristik semacam itu, negara-negara berlomba menggapai kemakmuran ekonomi lewat serangkaian penyelenggaraan pembangunan secara sistematis, dengan tujuan utama memuaskan masyarakat (individu). Secara material langkah-langkah pembangunan ekonomi sebagai suatu proses multidimensional yang melibatkan perubahanperubahan dalam struksur sosial, sikap-sikap yang sadar terbiasa dan lembaga-lembaga nasional termasuk percepatan / ekselerasi pertumbuhan ekonomi, pengangguran, katimpangan dan pemberantasan kemiskinan yang absolute (Todaro,2000: 13).

1 Corresponding Author 
Dengan demikian pembangunan ekonomi merupakan usaha suatu masyarakat untuk dapat mengembangkan kegiatan ekonomi dan mempertinggi tingkat pendapatan masyarakat, sedangkan usaha-usaha pembangunan secara keselurhan, meliputi juga usaha-usaha pembangunan sosial, politik dan kebudayaan. Dengan adanya pembtasan tersebut maka pertumbuhan ekonomi dapat didefinisikan sebagai suatu proses yang menyebabkan pendapatan perkapita penduduk suatu masyarakat meingkat dalam jangka panjang (Sukirno,2004: 13).

Menurut Kuncoro (1997 :103) kemiskinan adalah ketidakmampuan untuk memenuhi standar hidup minimum atau ketimpangan antara pendapatan dan pengeluaran. Menurut Sallatang (2005 : 55) kemiskinan adalah ketidak cukupan penerimaan pendapatan pemilikan kekayaan material, tanpa mengabaikan standart atau ukuran-ukuran fisiologi dan sosial.

Jumlah angka kemiskinan di Indonesia masih cukup tinggi. Badan Pusat Statistik Nasional mencatat jumlah angka kemiskinan di Indonesia pada bulan maret 2016 sebesar 28,01 juta orang atau $10,86 \%$, angka ini mengalami penurunan sebanyak 0,85 juta jiwa dari keadaan Maret 2015 dengan jumlah penduduk miskin sebanyak 28,59 juta jiwa atau $11,22 \%$, sehingga secara absolut maupun persentase, angka kemiskinan mengalami penurunan. (BPS, 2016)

Kabupaten Situbondo merupakan kota yang juga memiliki masalah kemiskinan. Jumlah kemiskinan di Kabupaten Situbondo mencapai 13,65 persen penduduk miskin dari 669.713 jumlah penduduk. Yaitu mencapai angka 90 ribu penduduk miskin di Kabupaten Situbondo. Jumlah ini menjadi Kabupaten Situbondo menempati posisi kedua persentase terbanyak penduduk miskin dari jumlah atau populasi penduduk daerah se tapal kuda atau Kerasidenan Besuki setelah Kabupaten Bondowoso.

Penelitian ini memilih Kecamatan Panarukan sebagai lokasi penelitian ini. Hal ini dikarenakan tingginya angka kemiskinan di kecamatan panarukan. Dari data yang diperoleh dari 8 kantor desa yang berada di Kecamatan Panarukan, terdapat 3.118 keluarga penduduk miskin penerima bantuan raskin. Jumlah tersebut sangat tinggi karena Kecamatan Panarukan adalah salah satu kecamatan percontohan di Kabupaten Situbondo. Selain itu Kecamatan Panarukan memiliki letak yang straegis, selain dekat dengan pusat kota, Kecamatan Panarukan memiliki letak geografis yang strategis, Sebelah utara Kecamatan Panarukan berbatasan langsung dengan selat Madura yang sangat berpotensi alam lautnya.

Hipotesis dari penelitian ini yaitu diduga terdapat hubungan positif antara pendidikan, jumlah partisipasi kerja, usia, dan jenis pekerjaan terhadap pendapatan keluarga miskin di Kecamatan Panarukan Kabupaten Situbondo.

Tujuan dari penelitian ini yaitu untuk mengetahui pengaruh pendidikan, jumlah partisipasi kerja, usia, dan jenis pekerjaan terhadap pendapatan keluarga miskin di Kecamatan Panarukan Kabupaten Situbondo.

\section{Metode}

\section{Jenis Penelitian}

Penelitian ini menggunakan metode deskriptif dan explanatory research. Penelitian deskriptif yaitu metode yang menggambarkan sistematis, faktual dan akurat mengenai fakta-fakta yang terjadi ditempat penelitian untuk kebenaran keadaan dan praktek yang berlangsung (Nazir, 1998 : 45). Explanatory Research merupakan penelitian yang menggunakan suatu metode yang menjelaskan secara sistematis, faktual dan akurat mengenai suatu objek yang diteliti yang bertujuan mencari ada tidaknya pola hubungan dan sifat hubungan antar dua variabel atau lebih, serta untuk menguji hipotesis bahkan menemukan teori baru (Nazir, 1998 :16).

\section{Unit Analisis}

Unit analisis dalam penelitian ini adalah keluarga miskin di Kecamatan Panarukan Kabupaten Situbondo dengan memberikan pertanyaan atau kuisioner yang berhubungan dengan pendidikan, jumlah partisipasi kerja dan usia.

\section{Populasi dan Sampel}

Populasi dalam penelitian ini adalah seluruh keluarga miskin yang menerima bantuan raskin di Kecamatan Panarukan Kabupaten Situbondo yang jumlah totalnya mencapai 3.118 kepala keluarga yang terbagi dalam 8 Desa yaitu Desa Wringin Anom sebanyak 275 KK, Kilensari 612 KK, Paowan 470 KK, Sumberkolak 615 KK, Alasmalang 226 KK, Pelean 285 KK, Gelung 367 KK, dan Desa Duwet 268 KK (Data Desa 2015) Sampel adalah sebuah sebagian dari anggota dari populasi yang dipilih dengan menggunakan ketentuan tertentu sehingga diharapkan dapat mewakili popuasinya (Sugiarto, 2003 : 23).

\section{Metode Analisis Data}

Untuk mengetahui pengaruh faktor pendidikan, jumlah partisipasi kerja dan usia terhadap pendapatan keluarga miskin di Kecamatan Panarukan Kabupaten Situbondo digunakan alat analisis persamaan linier berganda (Supranto, 19965 : 189).

$$
\mathrm{Y}=\beta_{0}+\beta_{1} \mathrm{X}_{1}+\beta_{2} \mathrm{X}_{2}+\beta_{3} \mathrm{X}_{3}+\beta_{4} \mathrm{X}_{4}+\mathrm{e}
$$

Dimana :

$\mathrm{Y}=$ Keluarga miskin

$\mathrm{X} 1=$ pendidikan,

$\mathrm{X} 2$ = Jumlah partisipasi kerja

$\mathrm{X} 3=$ Usia

$\mathrm{X} 4=$ Jenis pekerjaan

$\beta 0=$ intersep / konstanta

$\beta 1, \beta 2, \beta 3, \beta 4=$ koefisien regresi parsial

$\mathrm{e}=$ variabel Penganggu

Uji Statistik

Uji statistik dimaksudkan untuk mengetahui pengaruh variabel bebas terhadap variabel terikat. Dalam penelitian ini pengujian dilakukan untuk mengetahui apakah hipotesis yang telah ditentukan sebelumnya sesuai dengan kenyataan. Uji Hipotesis Yang Dilakukan Adalah :

Uji F

Untuk mengetahui secara simultaan (bersama-sama) koefisien regresi variabel pendidikan, jumlah tanggungan 
keluarga, curahan jam kerja, dan sifat pekerjan $\left(\mathrm{X}_{1}, \mathrm{X}_{2}, \mathrm{X}_{3}, \mathrm{X}_{4}\right)$ yang berpengaruh secara bersamaan (simultan) terhadap variabel terikat yakni pendapatan keluarga mskin (Y) (Supranto, 1995 :276).

\section{Uji t}

Uji parsial ini digunakan untuk mengetahui apakah masingmasing variabel bebas yakni pendidikan (X1), jumlah pertisipasi kerja (X2), usia (X3), dan jenis pekerjaan (X4) secara individu (parsial) mempengaruhi pendapatan (Y) dengan rumus sebagai berikut (supranto, 1995 : 162)

Koefisien Determinasi Berganda $\left(\mathrm{R}^{2}\right)$

Untuk mengetahui tingkat keeratan hubungan antara variabel independen dengan variabel dependen. Selanjutnya akan digunakan analisis koefisien determinasi berganda dan semakin besar nilai koefisien determinasi maka semakin tepat model regresi yang digunakan sebagai alat uji dalam penelitian ini. Dalam Gujarati (1995 : 46)

\section{Uji Ekonometrika}

\section{Uji Multikolinearitas}

Uji multikolinearitas digunakan untuk menguji model regresi akan terjadi hubungan yang sempurna atau hampir sempurna antara variabel bebas, sehingga sulit untuk memisahkan pengaruhnya antara variabel itu secara individu terhadap variabel terikat. Pendektesia n gejala multikolinearitas dapat dilakukan dengan melihat Variance Inflation Factor (VIF). Menurut Duwi Priyatno (2009) bahwa dalam banyak penelitian dijelaskan jika nilai VIF $<10$ maka model regresi tersebut bebas dari masalah multikolinearitas. Dalam penelitian ini akan digunakan pendekatan VIF.

\section{Uji Autokorelasi}

Uji auto korelasi digunakan intuk mengetahui ada tidaknya penyimpangan asumsi klasik auto korelasi yaitu korelasi yang terjaadi antara residual pada suatu pengamatan dalam sebuah model regresi. Untuk mengetahui ada tidaknya autokorelasi maka dibutuhkan sebuah metode pengujian Breusch=godfrey (Gujarati,2003 ; 58)

\section{Uji Heterokedastisitas}

Uji Heterokedatisitas digunakan untuk mengetahui ada atau tidaknya suatu penyimpangan asumsi klasik heterokedatisitas yaitu terdapatnya ketidaksamaan varian dari residual pada sebuah model regresi. Untuk melakukan sebuah pengujian diperlukan beberapa sebuah metode. Pada peneletian ini menggunakan uji White. Adapun langkah-langkah yang diperkenankan untuk pengujian Glejser (dalam Kuncoro, 2001:112)

Uji normalitas bertujuan untuk mengetahui apakah data yang berdistribusi normal. Yaitu data yang berditribusi bentuk lonceng (bell Shaped) atau data tersebut tidak menceng ke kiri atau ke kanan (Santoso, 2010, 43).

\section{Hasil dan Pembahasan}

\section{Hasil}

Analisis Regresi untuk mengetahui pengaruh niai pendidikan $\left(\mathrm{X}_{1}\right)$ jumlah partisipasi kerja $\left(\mathrm{X}_{2}\right)$ usia $\left(\mathrm{X}_{3}\right)$ dan jenis pekerjaan $\left(\mathrm{X}_{4}\right)$ terhadap pendapatan $(\mathrm{Y})$ bagi keluarga miskin di Kecamatan Panarukan Kabupaten Situbondo. Hasil analisis regresi linear berganda dapat diperoleh persamaan regresi linear berganda sebagai berikut ;

$$
\begin{aligned}
& \mathrm{Y}=\mathrm{b}_{0}+\mathrm{b}_{1} \mathrm{P}_{1}+\mathrm{b}_{2} \mathrm{JPK}_{2}+\mathrm{b}_{3} \mathrm{U}_{3}+\mathrm{b}_{4} \mathrm{JP}_{4}+\mathrm{e} \\
& \mathrm{Y}=209804.3+102486.0+577055.6-5738.553+183599.8
\end{aligned}
$$

Persamaan diatas dapat dijelaskan secara terperinci sebagai berikut ;

Nilai Konstanta $b_{0}$ (209804.3) besarnya kemiskinan responden sebesar 209804 satuan. Artinya variabel pendidikan, jumlah paartisipasi kerja, usia, dan jenis pekerjaan sama dengan konstan.

Nilai koefisien variabel pedidikan (x1) sebesar 102486.0 artinya setiap kenaikan satu tingkat lebih tinggi maka pendapatan penduduk miskin akan meningkat dan sebaliknya

Nilai koefisien variabel jumlah partisipasi kerja keuarga (x2) sebesar 577055.6 satuan. Artinya setiap bertambahnya satu anggota keluarga yang bekerja maka pendapatan keluarga miskin akan semakin meningkat dan sebaliknya.

Nilai koefisien variabel usia kepala keluarga (x3) sebesar -5738.553 satuan. Artinya setiap bertambahnya satu tahun usia kepala keluarga maka akan mengurangi tingkat pendapatan keluarga miskin dan sebaliknya.

Nilai koefisien variabel jenis pekerjaan (x4) sebesar 183599.8 satuan. Artinya setiap kepala keluarga yang bekerja diluar sektor pertanian sebagai buruh tani akan meningkatkan pendapatannya. daripada kepala keluarga yang bekerja di sektor pertanian sebagai buruh.

\section{Uji F (serentak)}

Uji F merupakan bagian dari uji statistik yang digunakan untuk mengukur dan mengetahui signifikasi keseluruhan dari variabel bebas (independen) yaitu pendidikan, jumlah partisipasi kerja keluarga, usia, dan jenis pekerjaan dimana dari seluruh variabel tersebut mampu menjelaskan variabel terikat (dependen) yaitu pendapatan. Dalam uji F statistik dapat diketahui apakah variabel bebas (independen) secara bersama-sama berpengaruh terhadap variabel terikat (dependen).

Dari hasil uji regresi maka diperoleh probabilitas F-statistic sebesar 0,000000 maka $\mathrm{H}_{0}$ ditolak dan $\mathrm{H}_{\mathrm{a}}$ diterima, karena nilai probabilitas F-statistic kurang dari nilai a sebesar 0,05 . Dari hasil uji tersebut maka variabel pendidikan, jumlah partisipasi kerja keluarga, usia, dan jenis pekerjaan secara bersama-sama berpengaruh signifikan terhadap pendapatan keluarga miskin di Kecamatan Panarukan Kabupaten Situbondo.

Uji $\mathrm{t}$ dalam analisis ini dimaksudkan untuk mengetahui tingkat signifikan pemgaruh secara parsial antara variabel bebas (independen) yang meliputi pendidikan, jumlah partisipasi kerja keluarga, usia, dan jenis pekerjaan terhadap variabel terikat (dependen) yaitu pendapatan. Dalam pengujian uji t terdapat syarat atau kriteria pengujian yaitu apabila nilai probabilitas t-statistic $<0,05$, maka $\mathrm{H}_{0}$ ditolak dan $\mathrm{H}_{1}$ diterima, yang berarti variabel bebas mempunyai pengaruh yang signifikan terhadap variabel terikat. 
Nilai probabilitas variabel pendidikan (x1) sebesar 0,0017 atau kurang dari nilai $\alpha=0,05$ artinya variabel independen pendidikan $(\mathrm{x} 1)$ berpengaruh signifikan terhadap variabel dependen yaitu pendapatan (Y).

Nilai probabilitas variabel jumah partisipasi kerja anggota keluarga (x2) sebesar 0,0000 atau kurang dari nilai $\alpha=0,05$ artinya, variabel independen jumlah partisipasi kerja anggota keluarga berpengaruh signifikan terhadap variabel dependen yaitu pendapatan $(\mathrm{Y})$.

Nilai probabilitas variabel usia (x3) sebesar 0,0531 atau lebih dari nilai $\alpha=0,05$ artinya variabel independen usia tidak memiliki pengaruh yang signifikan terhadap variabel dependen pendapatan (Y). Sedangkan apabila taraf nyata yang digunakan $10 \%$, variabel usia memiliki pengaruh yang negatif dan signifikan terhadap pendapatan (Y).

Nilai probabilitas variabel jenis pekerjaan $(\mathrm{x} 4)$ sebesar 0,0045 atau kurang dari nilai $\alpha=0,05$ artinya variabel independen jenis pekerjaan berpengaruh signifikan terhadap variabel dependen pendapatan $(\mathrm{Y})$.

\section{Pembahasan}

\section{Pengaruh Pendidikan terhadap Pendapatan}

Hasil regresi menunjukkan bahwa variabel tingkat pendidikan berpengaruh positif dan signifikan terhadap pendapatan keluarga miskin dengan koefisien sebesar 102486.0. Hal ini berarti semakin bertambahnya tingkat pendidikan maka semakin mudah untuk meningkatkan pendapatan. Teori Human Capital menjelaskan bahwa seseorang dapat meningkatkan pendapatannya melalui pendidikan. Setiap pertambahan satu tahun sekola berarti dapat meningkatkan kemampuan bekerja dan tingkat pendapatan seseorang. Selain itu juga dapat menunda penerimaan pendapatan dalam satu tahun mengikuti sekolah. Kemudian disamping penundaan tersebut orang yang melanjutkan sekolah harus membayar biaya secara langsung seperti uang sekolah, tambahan uang transport, dan lain-lain. (Simanjuntak, 1998:70).

\section{Pengaruh Jumlsh Partisipasi Keerja Terhadap Pendapatan}

Hasil penelitian menunjukkan bahwa pengaruh partisipasi kerja di dalam anggota keluarga berpenaruh positif dan signifikan dengan koefisien sebesar 577055.6. Artinya seakin banyaknya anggota keluarga yang bekerja maka akan meningkatkkan pendapatan keluarga itu sendiri. Menurut tjiptoherijanto (1992) dimana julah anggota keluarga yang bekerja akan mempengaruhi penghasilan satu keluarga itu sendiri, karena besar kecilnya jumlah anggota keluarga akan berpengaruh pada penghasilan suatu keluarga. Suatu rumah tangga yang mempunyai jumlah anggota keluarga yang lebih banyak bekerja akan berpenghasilan lebih besar daripada rumah tangga yang memiliki jumlah anggota keluarga lebih sedikit untuk bekerja sehingga tingkat pendapatan keluarga tidak sama. Dengan demikian, jumlah anggota keluarga yang ada dalam suatu rumah tangga akan mempengaruhi besar kecilnya pendapatan yang diterima keluarga.

\section{Pengaruh Usia Keluarga terhadap Pendapatan}

Hasil penelitian menunjukkan bahwa usia memberikan pengaruh yang negatif terhadap tingkat pendapatan keluarga miskin di Kecamatan Panarukan Kabupaten Situbondo, hal tersebut tidak cocok dengan landasan teori dikarenakan bahwa faktor usia tidak dapat dujadikan ukuran atau barometer tinggi rendahnya tingkat pendapatan keluarga miskin. Berdasarkan kondidsi di lapangan rata-rata penduduk keluarga miskin memiliki usia yang relatif telah menua yaitu berkisar 50-60 tahun, hal ini menunjukkan bahwa usia tersebut tidak produktif lagi, hal ini juga didukung dengan jenis pekerjaan responden yang mayoritas adalah sebagai pekerja kasar baik buruh tani maupun buruh nelayan serta pekerjaan yang tidak menetap yang juga meiliki waktu juga tidak tetap.

\section{Pengaruh Jenis Pekerjaan Terhadap Pendapatan}

Hasil penelitian menunjukkan variabel jenis pekerjaan memberikan pengaruh yang signifikan terhadap pendapatan keluarga miskin di Kecamatan Panarukan Kabupaten Situbondo. Dalam peneletian ini jenis pekerjaan di bagi menjadi dua yaitu penduduk yang bekerja di sektor pertanian sebagai buruh baik buruh nelayan maupun buruh tani, dan diluar sektor pertanian. Mayoritas penduduk di Kecamatan Panarukan Kabupaten Situbondo ini bekerja pada sektor pertanian. Masyarakat yang bekerja pada sektor pertanian yang khususnya sebagai buruh dapat menggambarkan kemiskinan seseorang, hal tersebut dikarenakan upah buruh yang begitu rendah, jam kerja yang tidak menentu, serta jenis pekerjaan tersebut yang dapat digolongkan sebagai jenis pekerjaan yang kasar.

\section{Simpulan}

Pendidikan menunjukkan pengaruh yang positif dan signifikan terhadap pendapatan keluarga miskin di Kecamatan Panarukan Kabupaten Situbondo. Hal ini berarti bahwa semakin tingginya tingkat pendidikan maka akan semakin tinggi pula pendapatan yang akan diperoleh. Jumlah partisipasi anggota keluarga menunjukkan pengaruh positif dan signifikan terhadap pendapatan keluarga miskin di Kecamatan Panarukan Kabupaten Situbondo. Hal ini berarti semakin tingginya atau banyaknya jumlah anggota keluarga yang bekerja maka akan dapat meningkatkan pendapatan keluarga miskin di Kecamatan Panarukan Kabupaten Siubonndo. Usia tidak memberikan pengaruh yang negatif signifkan apabila nilai taraf nyata $\alpha=5 \%$ terhadap pendapatan keluarga miskin di Kecamatan Panarukan Kabupaten Situbondo. Sedangkan apabila nilai taraf nyata yang dipakai $\alpha=10 \%$ maka usia berpengaruh negatif dan signifikan terhadap pendapatan keluarga. Jenis pekerjan memberikan pengaruh yang signifikan terhadap pendapatan keluarga di Kecamatan Panarukan Kabupaten Situbondo. Jenis pekerjaan pada sektor pertanian sebgai buruh dpat dikatakan memiliki potensi tingkat kemiskinan yang lebih tinggi daripada di luar sektor pertanian. Hal tersebut dikarenakan pekerjaan buruh tani yang tidak menentu dan tidak tetap yang dapat mempengaruhi terhadap pendapatan yang tidak menetap dan tergolong kecil.

\section{Ucapan Terima Kasih}

Penulis mengucapkan terima kasih kepada pembimbing yang telah bersedia membimbing selama proses penelitian dan tugas akhir.

\section{Referensi}

Badan Pusat Statistik Kab. Situbondo. Fenomena Kemiskinan Situbondo. 2015 
Badan Pusat Statistik Prov Jatim..Profil Kemiskinan Jawa Timur.2015

Gujarati, D. 1995. Ekonometrika Dasar. Jakarta. Kumarian

Kuncoro, Mudrajat.2000. Ekonomi Pembangunan. Yogyakarta : UPPAMP.YKPN

Nazir, M. 1998. Metode penelitian. PT. Ghalia Indonesia, Jakarta.

Priyatno Duwi. 2009. SPSS “ Untuk Analisis Korelasi, Regresidan Multivariate". Yogyakarta : Gaya Media

Todaro, Michael. 1987. Economic Fora Developing World. Erlangga : Jakarta
Sallatang, M.A.,2005. Kemiskinan dan Mobiitas Pembangunan (Makalah), Lembaga Penerbitan Unhas, Ujung Pandang.

Santoso, Singgih. 2010. Statistik Multivariat, Jakarta : PT

Simanjuntak. Payaman. 1998. Ekonomi Sumberdaya Maanusia. Jakarta. LPEE-UI.

Sugiarto. 2003. Teknik Sampling. Jakarta : Gramedia Pustaka Utama.

Sukirno, Sadono. 2004. Makro Ekonomi Teori Pengantar. Jakarta: PT Raja Grafindo Perkasa.

Supranto, J, MA.1995, Statistik Bidang Hukum, Penerbit PT Bineka Cipta. 